\title{
DISCURSO PROFERIDO QUANDO DA ENTREGA DO TÍTULO DE PROFESSOR EMÉRITO (USP)
}

http://dx.doi.org/10.11606/issn.2237-1184.v0i26p180-182

Boris Schnaiderman

É com grande emoção, que recebo este título que me é concedido pela nossa Faculdade. Pondo entre parênteses a solenidade de sessões como estas, aproveitei a ocasião para fazer um exame de consciência e agora chego à conclusão de que recebi muito mais do que dei. Digo isto sem nenhuma falsa modéstia, sem nenhum recurso retórico, mas, simplesmente, pela rememoração do caminho percorrido.

Iniciei em 1960 as minhas atividades como professor do Curso Livre de Russo, quando já estava desligado da profissão de engenheiro agrônomo e trabalhava na redação de uma enciclopédia. Foi simplesmente incrível a boa vontade e o carinho com que fui recebido pelos novos colegas. Completamente ignorante das normas universitárias, fui ajudado em todos os primeiros passos na ocupação nova para mim. Foram muitos os que me apoiaram. No entanto, preciso fazer menção especial ao Prof. Dr. Antonio Candido, que sempre confiou em mim, em todos os momentos me deu mão forte, inclusive naqueles mais duros, e me acolheu entre os seus orientandos, quando isso se tornou indispensável para o ingresso na carreira universitária.

Os anos passados no prédio da Maria Antônia me deixaram profundamente marcado. Vivíamos ali um cotidiano que não vi em nenhuma outra universidade nas viagens que realizei depois. Ainda não se falava em interdisciplinaridade, mas era o que se praticava diariamente. No café da esquina, conversávamos com os colegas das áreas mais diversas, trocávamos experiências e impressões e, certamente, isso contribuiu para a ampliação dos horizontes. Por conseguinte, neste caso pelo menos, a nossa pobreza de recursos materiais, instalados naquele prédio tão precário e inadequado, contribuía para a experiência do 
verdadeiro espírito universitário. Um simples cafezinho e uma conversa amistosa não valia menos que eventuais encontros em simpósios internacionais.

Seguiram-se anos tristes, dos quais nem gosto de recordar, mas com satisfação constato que, apesar de todas as dificuldades, o curso de russo de nossa Faculdade foi o único que sobreviveu a todas as tormentas, embora, em 1964, existisse cursos desse tipo em diversas universidades do país, surgidos na esteira das conquistas espaciais russas.

Não foi fácil, mas o que então sofri era muito pouco em comparação com os sacrifícios de tantos outros colegas. Naqueles anos todos contei sempre com o apoio da Profa. Regina Chnaiderman e dos meus filhos Miriam e Carlos.

Devo também lembrar, da abnegação de tantos que me ajudaram a tocar em frente o Curso de Russo. Tivemos então, a ajuda de jovens que se prontificavam a lecionar sem qualquer remuneração, uma prática realmente condenável, mas da qual não pude me eximir. Alguns deles, estão hoje lecionando em outros setores, mas eu me lembro de todos eles e do quanto eu lhes fiquei devendo em momentos difíceis. Uns poucos, acabaram ingressando nos quadros do curso e deles recebi apoio em todas as ocasiões. Na realidade passamos juntos por um aprendizado difícil em uma área de ensino completamente nova no país. Pudemos realizar algumas viagens de estudo e vendo os resultados que eles atingiram chego à conclusão de que valeu a pena.

Aliás, quero lembrar, com ênfase especial, dois professores que foram meus alunos e depois, sucessivamente, orientandos e colaboradores, e que não estão mais entre nós. Sophia Angelides e Paulo Dal Ri Perez, ambos nos deixaram depois de dedicar o melhor de seus esforços para o desenvolvimento do curso. Sobretudo, foram pessoas de qualidade humana invulgar, além de estudiosos que nos legaram textos importantes. Felizmente, pude continuar trabalhando, corrigindo e melhorando o que deixei publicado.

Nos últimos quinze anos, pude contar com a ajuda constante de minha mulher, a Profa. Gerusa Pires Ferreira, a quem devo tudo que realizei neste período, pois, de outro modo, não conseguiria superar as dificuldades que surgiram. Digo isso sem nenhum exagero. É apenas a constatação de um fato.

Finalizando, devo agradecer a concessão desse título pela Faculdade e a brilhante alocução de minha colaboradora de muitos anos e amiga, Profa. Dra. Aurora Fornoni Bernardini. Muito obrigado. 


\section{Considerações finais pelo Prof. Dr. Francis Henrik Aubert, Diretor da Faculdade de Filosofia, Letras e Ciências Humanas}

Em algum momento, os Cursos de Russo foram estabelecidos, aqui na USP e em outras instituições, não por razões linguísticas, literárias ou culturais, mas, provavelmente, motivados por questões de natureza geopolíticas. Hoje, com toda a crise que a ex-União Soviética vem passando, a importância geopolítica desses cursos talvez tenha, apenas aparentemente, se perdido ou não se encontre tão visível. Em compensação, o momento é extremamente favorável aos verdadeiros valores da cultura russa, da língua, da história, da literatura, das artes, dos diversos exemplos do povo russo em todas as suas adversidades que não são apenas do século XIX, XX e XXI, mas remontam de longa data. Pelo menos, dos tempos que os meus antepassados por lá adentraram e resolveram barbarizar - eu sou descendente de Vikings e, por isso, tenho uma percepção clara desse problema. Talvez, esse seja o momento em que todos esses valores encontrem um tempo mais favorável para se manifestar. Eu tenho muita fé, como a Profa. Aurora e o Prof. Boris, que ao contrário do que possa parecer por conta das múltiplas crises, não só na Rússia como no Brasil, este seja o momento que pode se mostrar extremamente frutífero para o resgate dos mesmos.

Por todo o papel que, nesse processo, o Prof. Boris representou e continua representando, por esse trabalho que, muito mais modestamente do que ele, eu também tenho tentado fazer em relação aos países nórdicos - esse difícil papel de ponte, de quem, de alguma forma, é obrigado a deitar raízes em duas culturas e duas visões de mundo diferentes e viver permanentemente em conflito entre essas duas verdades de sua própria pessoa - por todo esse esforço e brilhantismo com que ele conduziu essa difícil tarefa, gostaria em meu nome, em nome da Congregação e da Faculdade como um todo, de fazer o meu mais profundo e sincero agradecimento. 